\title{
USING OF SOME MATHEMATICAL MODELS TO PREDICT THE GROUNDWATER QUALITY AND SOIL PRODUCTIVITY IN EL ARISH VALLEY AREA, NORTH SINAI, EGYPT Fayed, R. M. ; Gamal Abdel Nasser ${ }^{\star *}$ and Kh. G. A. Abd Alazim ${ }^{\star *}$ * Soils and Water Department, Faculty of agric. Al Azhar, Univ. \\ National Water Research Center
}

\begin{abstract}
Groundwater is considered the main source of water in north Sinai at El Arish area.The groundwater level withdraw and the salinity of the water increased due to the increasing groundwater discharge and the decreasing of recharge from the rainfall. This study aims at identifying the impact of continuous pumping on groundwater quality and soil productivity in El Arish area. Historical data of some wells were used to predict the groundwater quantity and quality changes through using MODFLOW and MT3DMS models. Prediction of groundwater salinity was assessed under three scenarios which considered the increasing of pumping in both absence and occurrence of groundwater recharge from the rainfall. By using the predicted data of groundwater from the model, the soil salinity was calculated by using the equation of FAO (1985) $\mathrm{EC}_{e}=E C$ * 1.5. The calculated values of the soil salinity indicated that the continuous pumping will cause potential increase in water salinity and subsequently the soil salinity will increase. Due to the FAO standard, the yield of tolerant crops will decrease sharply.
\end{abstract}

\section{INTRODUCTION}

People in Sinai depend on the groundwater as a main source of water due to the lack of rainfall. Therefore, they use it to cover their needs of agricultural and domestic uses. This water is discharged from the quaternary aquifer systems which extend along El-Arish valley and its surroundings. The aquifer in the area of the study is represented by three aquifer systems. The sand dune tapped the system from the surface and underlain by alluvial deposits which overlain the Kurkar (calcareous sand stone) aquifer system (JICA, 1992).

The rapid increase of population means an increase of the water demands, subsequently the abstraction of the groundwater increases. This may cause the salt concentration of that water increases and affects the crops productivity.

The problem of salinity is increasing day by day in most arid and semiarid countries of the Mediterranean Sea imposing drastic damage not only on soil productivity and food production, but also on the region development as a whole. (Lacirignola et al., 2002).

The continuous pumping of groundwater in El Arish area to be used for domestic and agricultural uses to cope with the increasing of population and their great needs from crops, vegetables and fruits led to disturbance in the water balance. This occurred due to the big quantities of extracted groundwater versus the low recharge from the rainfall. With the increase in the rates of withdrawal from the groundwater and in case of the lack of control of the continuous pumping, the pezometric heads of the aquifers have 
been decreased. Due to the locations of the studied groundwater wells of the current study which are very close to the sea and the soil structure which is sandy, a connection between the sea water and the groundwater in the studied area might occur. This phenomenon may cause the sea water intrusion to compensate the continuous discharge from the groundwater and hence increases the groundwater salinity. This saline groundwater may increase the soil salinity and may cause negative impacts on crop yields. The slow changes in groundwater quantity and quality, which need several years to be observed, the mathematical models, can be used to predict the groundwater flow and its salinity due to the continuous pumping, depending on previous results considering the wells locations, groundwater levels, discharges, climate conditions and the cultivated crops. Therfore the current study aims at studying the impact of continuous pumping on the groundwater quality, soil salinity and crop yields in El Arish area.

\section{MATERIALS AND METHODS}

\section{1- Site description}

The study area falls between Latitudes : $31^{\circ} 05^{\prime} 00^{\prime \prime}$ and $31^{\circ} 08^{\prime} 00^{\prime \prime} \mathrm{E}$, and Longitudes : $33^{\circ} 48^{\prime} 00^{\prime \prime}$ and $33^{\circ} 5^{\prime} 1^{\prime} 00^{\prime \prime} \mathrm{N}$ between Lehfen in the south, El Kharrouba in the east, El- Masaeid in the west, and the Mediterranean Sea in the north. The wells selected for implementing the study area are located in El-Arish area in North Sinai. Figure (1) presents the layout of 30 wells selected to cover all the study area. Groundwater wells are considered the main water sources for irrigation of farms in the area of study, in addition to the rainfall that might occur in there.

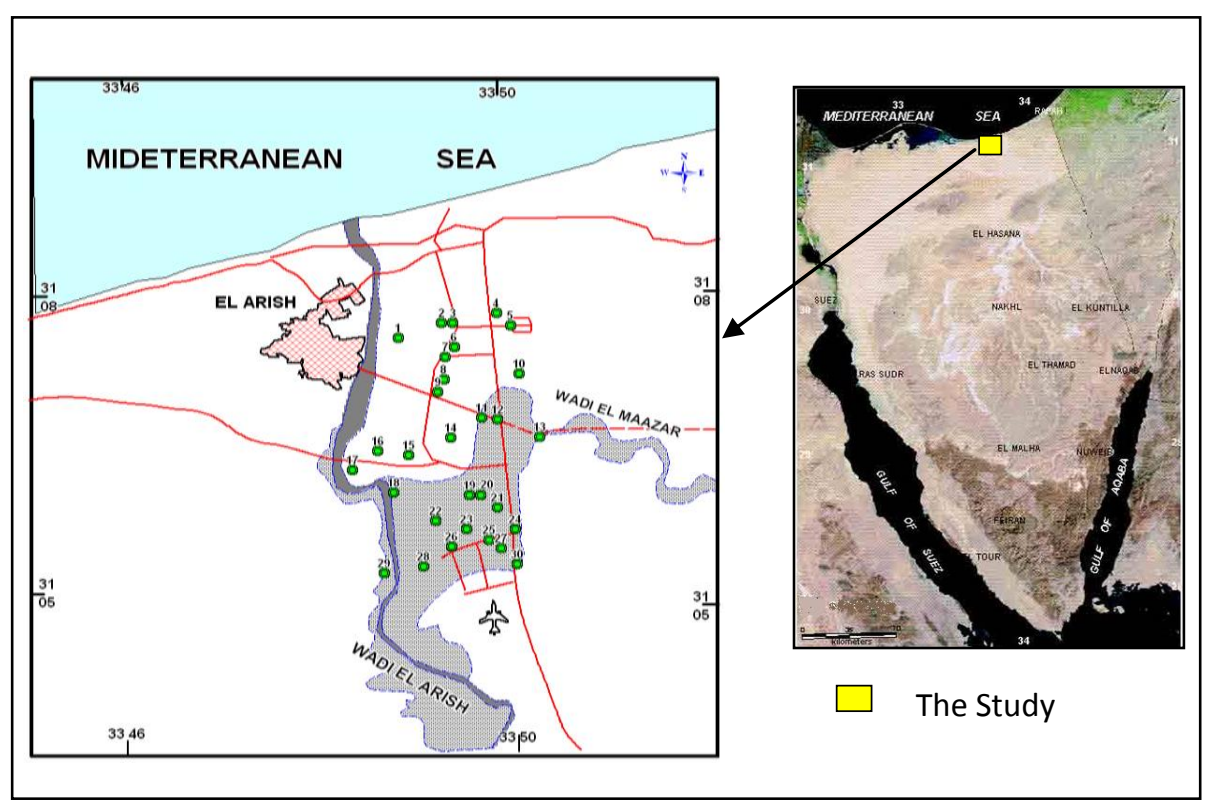

Figure (1): Groundwater wells locations in the study area 


\section{Hydrogeology of El Arish area \\ Aquifer system}

This aquifer occurs along the coastal belt and is composed of continuous layers from the sand dunes in the upper part, wadi deposits or beach deposits in the middle part while the lower one is composed of calcareous sandstone called locally as kurkar.

\section{Soil sampling}

Soil samples were collected during 2012 from the different areas irrigated with the studied wells groundwater. The soil samples were collected from the depths of $(0-30 \mathrm{~cm}),(30-60 \mathrm{~cm})$ and $(60-90 \mathrm{~cm})$.

Soil physical analyses were carried out as follow:

- Soil texture according to the pipette method of Piper (1950).

- Soil bulk density according to Black (1965).

- Moisture constants i.e. field capacity and wilting point according to Walker and Skogerboe (1987).

Soil chemical analyses were carried out as follow:

- pH according to Richards (1954) and EC according to Jackson (1973).

- Soluble cations $\left(\mathrm{Na}^{+}, \mathrm{K}^{+}, \mathrm{Ca}^{2+}\right.$ and $\left.\mathrm{Mg}^{2+}\right)$ as well as soluble anions $\left(\mathrm{CO}_{3}{ }^{2-}\right.$, $\mathrm{HCO}_{3}{ }^{-}, \mathrm{SO}_{4}{ }^{2-}$ and $\mathrm{Cl}^{+}$) according to Richards (1954)

- O.M according to Walkley and Black's method (Jackson, 1973).

- $\mathrm{CaCO}_{3}$ by using Collin's Calcimeter Method according to Hesse (1971).

Table (1) Particle size distribution, moisture constants, organic matter content and calcium carbonate content in the surface soil layer $(0-30 \mathrm{~cm})$ of the study area.

Table (1): Some physical properties of the surface soil layer $(0-30 \mathrm{~cm})$ of some studied samples

\begin{tabular}{|c|c|c|c|c|c|c|c|c|c|c|}
\hline \multirow{2}{*}{$\begin{array}{c}\text { sample } \\
\text { No. }\end{array}$} & \multicolumn{3}{|c|}{$\begin{array}{l}\text { Particle size } \\
\text { distribution }\end{array}$} & \multirow{2}{*}{$\begin{array}{c}\text { Textural } \\
\text { Class }\end{array}$} & \multirow{2}{*}{$\begin{array}{l}\text { Bulk } \\
\text { density } \\
\text { kg m}^{-3}\end{array}$} & \multicolumn{3}{|c|}{\begin{tabular}{|c|}
$\begin{array}{c}\text { Moisture content } \\
\% \\
\text { by volume }\end{array}$ \\
\end{tabular}} & \multirow{2}{*}{$\underset{\mathrm{g} \mathrm{kg}}{\mathrm{OM}}$} & \multirow{2}{*}{$\begin{array}{c}\mathrm{CaCO}_{3} \\
\mathrm{~g} \mathrm{~kg}^{-1}\end{array}$} \\
\hline & $\begin{array}{c}\text { Fine } \\
\text { Sand } \\
\%\end{array}$ & $\begin{array}{c}\text { Coarse } \\
\text { Sand } \\
\%\end{array}$ & \begin{tabular}{|c|} 
(Silt \\
+ Clay) \\
$\%$
\end{tabular} & & & F.C. & W.P & A.W & & \\
\hline 1 & 12.0 & 85.0 & 3.0 & Sandy & 1.70 & 16.2 & 8.2 & 8.0 & 2.0 & 54 \\
\hline 2 & 10.4 & 86.2 & 3.4 & Sandy & 1.65 & 15.0 & 7.8 & 7.2 & 2.0 & 53 \\
\hline 3 & 8.2 & 88.3 & 3.5 & Sandy & 1.70 & 16.0 & 7.9 & 8.1 & 2.8 & 54 \\
\hline 4 & 11.6 & 86.4 & 2.0 & Sandy & 1.67 & 14.0 & 7.7 & 6.3 & 2.5 & 51 \\
\hline 5 & 9.0 & 86.0 & 5.0 & Sandy & 1.65 & 16.7 & 7.5 & 9.2 & 3.5 & 49 \\
\hline 6 & 10.0 & 85.6 & 4.4 & Sandy & 1.70 & 15.8 & 8.2 & 7.6 & 2.8 & 50 \\
\hline 7 & 7.0 & 89.0 & 4.0 & Sandy & 1.70 & 16.2 & 8.3 & 7.9 & 2.6 & 52 \\
\hline 8 & 6.5 & 90.0 & 3.5 & Sandy & 1.69 & 15.8 & 7.9 & 7.9 & 2.5 & 58 \\
\hline 9 & 6.8 & 90.0 & 3.2 & Sandy & 1.69 & 16.6 & 8.1 & 8.5 & 2.0 & 51 \\
\hline 10 & 8.1 & 88.0 & 3.9 & Sandy & 1.66 & 16.4 & 8.5 & 7.9 & 2.3 & 50 \\
\hline 11 & 7.5 & 87.7 & 4.8 & Sandy & 1.65 & 17.0 & 8.2 & 8.8 & 3.4 & 48 \\
\hline 12 & 9.2 & 86.5 & 4.3 & Sandy & 1.70 & 15.9 & 7.8 & 8.1 & 3.0 & 47 \\
\hline
\end{tabular}


Only two areas were selected for the soil sampling in year 2013.Those two areas are irrigated from well No.(5) and well No.(12) which have been studied before in year 1992,(JICA,1992), in order to follow the changes that might occur in some chemical properties of the soil due to the changes of the groundwater quality as shown in Tables (2) and (3).

Table (2): Chemical characteristics of the soil irrigated with well water No. (5)

\begin{tabular}{|c|c|c|c|c|c|c|c|c|c|c|c|}
\hline \multirow{2}{*}{ Year } & \multirow{2}{*}{ Depth } & \multirow{2}{*}{$\begin{array}{c}\mathrm{EC}_{\mathrm{e}} \\
\mathrm{dS} / \mathrm{m}\end{array}$} & \multirow{2}{*}{ pH } & \multicolumn{4}{|c|}{ Cations $\left(\mathrm{m} \mathrm{mol}_{\mathrm{c}} \mathrm{L}^{-1}\right)$} & \multicolumn{3}{|c|}{ Anions (m mol ${ }_{c} \mathrm{~L}^{-1}$ ) } & \multirow{2}{*}{ SAR } \\
\hline & & & & $\mathbf{K}^{+}$ & $\mathrm{Na}^{+}$ & $\mathrm{Mg}^{++}$ & $\mathrm{Ca}^{++}$ & $\mathrm{Cl}^{-}$ & $\mathrm{SO}_{4}{ }^{--}$ & $\mathrm{HCO}_{3}$ & \\
\hline \multirow{3}{*}{1992} & $0-30$ & 2.02 & 7.80 & 0.57 & 14.20 & 4.18 & 2.17 & 12.50 & 4.02 & 4.60 & 7.97 \\
\hline & $30-60$ & 2.55 & 7.85 & 0.65 & 18.50 & 4.96 & 2.88 & 16.70 & 5.64 & 4.65 & 9.34 \\
\hline & $60-90$ & 2.90 & 7.75 & 0.65 & 20.00 & 6.00 & 3.00 & 18.70 & 6.55 & 4.40 & 9.43 \\
\hline \multirow{3}{*}{2012} & $0-30$ & 3.80 & 7.80 & 0.92 & 24.00 & 11.50 & 4.70 & 22.30 & 14.02 & 4.80 & 8.43 \\
\hline & $30-60$ & 4.12 & 7.70 & 1.02 & 25.40 & 12.70 & 5.18 & 23.80 & 16.10 & 4.40 & 8.50 \\
\hline & $60-90$ & 5.26 & 7.80 & 1.10 & 33.00 & 14.80 & 6.22 & 31.40 & 19.12 & 4.60 & 10.18 \\
\hline \multirow{3}{*}{2013} & $0-30$ & 3.86 & 7.80 & 1.16 & 24.60 & 11.90 & 4.22 & 22.80 & 14.38 & 4.70 & 8.66 \\
\hline & $30-60$ & 4.36 & 7.65 & 1.22 & 26.20 & 13.03 & 5.66 & 26.65 & 14.91 & 4.55 & 8.57 \\
\hline & $60-90$ & 5.50 & 7.75 & 1.22 & 33.80 & 15.60 & 6.58 & 32.40 & 20.12 & 4.68 & 10.15 \\
\hline
\end{tabular}

Table (3): Chemical characteristics of the soil irrigated with well water No. (12)

\begin{tabular}{|c|c|c|c|c|c|c|c|c|c|c|c|}
\hline \multirow[b]{2}{*}{ Year } & \multirow{2}{*}{ Depth } & \multirow{2}{*}{$\begin{array}{c}\mathrm{EC}_{\mathrm{e}} \\
\mathrm{dS} / \mathrm{m}\end{array}$} & \multirow{2}{*}{ pH } & \multicolumn{4}{|c|}{ Cations $\left(\mathrm{m} \mathrm{mol}_{\mathrm{c}} \mathrm{L}^{-1}\right)$} & \multicolumn{3}{|c|}{ Anions (m mol $\mathrm{L}^{-1}$ ) } & \multirow{2}{*}{ SAR } \\
\hline & & & & $\mathbf{K}^{+}$ & $\mathrm{Na}^{+}$ & $\mathrm{Mg}^{++}$ & $\mathrm{Ca}^{++}$ & $\mathrm{Cl}^{-}$ & $\mathrm{SO}_{4}{ }^{--}$ & $\mathrm{HCO}_{3}$ & \\
\hline \multirow{3}{*}{1992} & $0-30$ & 3.22 & 7.80 & 1.12 & 19.70 & 8.50 & 5.22 & 18.00 & 12.34 & 4.20 & 7.52 \\
\hline & $30-60$ & 4.80 & 7.85 & 1.25 & 33.20 & 9.16 & 5.58 & 31.10 & 13.89 & 4.20 & 12.23 \\
\hline & $60-90$ & 5.11 & 7.70 & 1.30 & 35.40 & 10.10 & 5.92 & 32.60 & 16.12 & 4.00 & 2.51 \\
\hline \multirow{3}{*}{2012} & & 4.85 & 7.85 & 1.36 & 30.00 & 10.96 & 6.12 & 28.40 & 15.84 & 4.20 & 10.27 \\
\hline & $30-60$ & 6.52 & 7.85 & 1.41 & 43.00 & 13.80 & 6.52 & 40.20 & 20.23 & 4.30 & 13.49 \\
\hline & $60-90$ & 7.33 & 7.80 & 1.48 & 51.40 & 15.70 & 6.88 & 47.20 & 24.01 & 4.25 & 15.30 \\
\hline \multirow{3}{*}{2013} & $0-30$ & 4.98 & 7.80 & 1.36 & 31.20 & 11.18 & 6.30 & 29.40 & 16.44 & 4.20 & 10.55 \\
\hline & $30-60$ & 6.83 & 7.85 & 1.45 & 45.00 & 14.16 & 6.42 & 43.20 & 19.53 & 4.30 & 14.03 \\
\hline & $60-90$ & 7.47 & 7.80 & 1.49 & 51.60 & 16.18 & 7.09 & 47.50 & 24.56 & 4.30 & 15.13 \\
\hline
\end{tabular}

\section{Water analysis}

Data of the groundwater wells were collected from previous reports as well as direct field measurements.Water samples were analyzed using the standard methods outlined by USDA (2004).

\section{Groundwater Models:}

The MODFLOW mathematical model was used to predict the progress of the water salinity due to the continuous pumping on the groundwater from wells.

\section{MODFLOW}

MODFLOW is groundwater model that was first published in 1984 by the U.S. Geological Survey. It has a modular structure that allows it to be easily modified to adapt the code for a particular application. Many new capabilities have been added to the original model, which is called MODFLOW-2000 in order to distinguish it from earlier versions. MODFLOW is a modular three dimensional finite difference groundwater model and is an easy to use modeling environment for practical applications related to groundwater.MODFLOW-2000 simulates steady and transient flow in an 
irregularly shaped flow system in which aquifer layers can be confined, unconfined, or be a combination of confined and unconfined.

\section{MT3DMS}

Modular Three Dimensional Transport model of Multi-species structure for accommodating add-on reaction packages.MT3DMS has a comprehensive set of options and capabilities for simulating advection, dispersion/diffusion, and chemical reactions of contaminants in groundwater flow systems under general hydrogeological conditions. It is used with any block-centered finite-difference flow model such as MODFLOW and is based on the assumption that changes in the concentration field will not affect the flow field significantly.MT3DMS can be used to simulate changes in concentrations of miscible contaminants in groundwater considering dispersion, diffusion and chemical reactions, with various types of boundary conditions and external sources or sinks.

Proposed scenarios

In order to study the future impacts of the groundwater on the soil and crop productivities, three scenarios were considered to predict the future drawdown and the salinity of the groundwater as follow:

The first scenario: Increasing the abstraction of groundwater from existing wells in the study area by $5 \%$ every year for next10 years up to (2023) assuming that these years are drought years (no rainfall)

The second scenario: Increasing the abstraction of groundwater from existing wells in the study area by $5 \%$ every year for next 20 years up to (2033) assuming that these years are drought years (no rainfall).

The third scenario: Increasing the abstraction of groundwater from existing wells in the study area by 5\% every year for next 20 years up to (2033) assuming that these years are rainy years.

\section{Soil and crop productivity assessment}

The equations of $F A O$ were used as follow:

$\mathrm{FAO}$ (1985): $\mathrm{EC}_{\text {soil }}=\mathrm{EC}_{\text {water }}{ }^{*} 1.5$

Where

ECsoil is the electrical conductivity of the saturation extract of the soil

ECwater is the electrical conductivity of the irrigation water

It was used to predict the future impact of increasing the salinity of groundwater due to the continuous pumping on the soil salinity.

FAO (1985) : $Y=100-b\left(E C_{e}-a\right)$

Where:

$\mathrm{Y}=$ Relative crop yield (percent)

$\mathrm{EC}_{\mathrm{e}}=$ Salinity of the soil saturation extract

a $=$ Salinity threshold value

$\mathrm{b} \quad=$ Yield loss per unit increase in salinity

It is also important to study the impact of soil salinity on the crop yields. 


\section{RESULTS AND DISCUSSION}

\section{Characteristics of El-Arish Soil \\ Physical and chemical properties}

Soils of the study area are characterized by a sandy texture. Values of thier bulk density ranged between 1.6 to $1.7 \mathrm{~kg} \mathrm{~m}^{3}$ which coincide with the sandy texture soil. These results are in agreement with those obtained by Aşkin and Özdemir (2003) who reported that sandy soils have relatively high bulk density since total pore space in sands is less than those of the silty or clayey soils.

Moisture content at the field capacity ranged between 14 to $17 \%$ while the values of moisture content at the wilting point of the studied soil samples ranged between 7.4 to $8.5 \%$. Subsequently, the values of the available water which represent the difference between the moisture content at field capacity and the corresponding moisture content at wilting point, ranged between 6.3 to $9.2 \%$. These results were in agreement with NRCCA (2009) who found that the volumetric soil moisture content remaining at field capacity is about 15 to $25 \%$ for sandy soils while the volumetric soil moisture content at the wilting point is around 5 to $10 \%$. In addition, they demonstrated that the available water ranged between $5-15 \%$ in sandy soils.

The organic matter content ranged between 2.0 to $3.5 \mathrm{~g} \mathrm{~kg}^{-1}$. The differences between the values of organic matter in the studied soil samples may be attributed to variations in types of cultivated plants and also quality and quantity of the organic applied fertilizers. All the soil samples were low in organic matter in sandy and sandy loam soils as indicated by Singh et al. (2007).

$\mathrm{CaCO}_{3}$ content ranged between 47 to $61 \mathrm{~g} \mathrm{~kg}^{-1}$.

\section{Soil salinity}

It is important to follow up the changes that might occur in soil salinity owing to their continuous irrigation with well waters to know:

- Whether the soil need to leaching process or not.

- The most suitable crop pattern that can be cultivated in the soil

- The impact of the soil salinity on the crops yield

Tables (2) and (3) reveal the chemical properties of the soils irrigated with the groundwaters of wells 5 and 12 . It is clear from the data that there were obvious increases in the soil salinity values and their contents of soluble cations and anions due to the increase of the EC of the irrigation water. The comparison between the salinity values of 2012 with those of 2013, reveals that the differences were slight due to the short time and also due to the coarse texture of the soil that allowed the irrigation water to drain vertically to the deeper layers. The increases in the soil EC values were corresponding to the increases of salinity of irrigation water which followed the same trend. The changes in $\mathrm{pH}$ values of the studied soils were not obvious. The data also reveal that the increases in soluble cations and anions were corresponding to increases in the EC values. The data show that the carbonate was absent and the dominant salt was sodium chloride $(\mathrm{NaCl})$. The neutral values of $\mathrm{pH}$ are probably due to the dominancy of $\mathrm{NaCl}$ in the soil. 
Tables (4) and (5) reveal that the EC of the soil increased from year 1992 to year 2012 by $76.3 \%$ and $42.2 \%$ for the surface layer of the soil irrigated from the water of wells 5 and 12, respectively while the increases in EC of the surface layers were $4.1 \%$ and $3.2 \%$ only for the soils irrigated with wells water 5 and 12 from the year 2012 to year 2013, respectively.

Table (4): Comparison between chemical soil analysis in year 2012 and 2013 as percentage corresponding to year 1992 at the around area of well No.5

\begin{tabular}{|c|c|c|c|c|c|}
\hline & $\mathbf{1 9 9 2}$ & $\mathbf{2 0 1 2}$ & $\mathbf{2 0 1 3}$ & \%(1992-2012) & \%(2012-2013) \\
\hline $\mathrm{ECe}(\mathrm{dS} / \mathrm{m})$ & 2.49 & 4.39 & 4.57 & 76.3 & 4.1 \\
\hline $\begin{array}{c}\mathrm{K} \\
\mathrm{m} \mathrm{mol}_{\mathrm{c}} \mathrm{L}^{-1}\end{array}$ & 0.62 & 1.01 & 1.20 & 62.6 & 18.4 \\
\hline $\begin{array}{c}\mathrm{Na} \\
\mathrm{m} \mathrm{mol}_{\mathrm{c}} \mathrm{L}^{-1}\end{array}$ & 17.57 & 27.47 & 28.20 & 56.4 & 2.7 \\
\hline $\begin{array}{c}\mathrm{Mg} \\
\mathrm{m} \mathrm{mol}_{\mathrm{C}} \mathrm{L}^{-1}\end{array}$ & 5.05 & 13.00 & 13.51 & 157.6 & 3.9 \\
\hline $\begin{array}{c}\mathrm{Ca} \\
\mathrm{m} \mathrm{mol}_{\mathrm{C}} \mathrm{L}^{-1}\end{array}$ & 2.68 & 5.37 & 5.49 & 100.0 & 2.2 \\
\hline $\begin{array}{c}\mathrm{Cl}_{\mathrm{m} \mathrm{mol}} \mathrm{L}^{-1} \\
\begin{array}{c}\mathrm{SO} 4 \\
\mathrm{~m} \mathrm{~mol}_{\mathrm{C}} \mathrm{L}^{-1}\end{array}\end{array}$ & 15.97 & 25.83 & 27.28 & 61.8 & 5.6 \\
\hline $\begin{array}{c}\mathrm{HCO} 3 \\
\mathrm{~m} \mathrm{~mol}_{\mathrm{c}} \mathrm{L}^{-1}\end{array}$ & 4.55 & 4.60 & 4.64 & 1.1 & 0.3 \\
\hline
\end{tabular}

* Values of EC and soluble ions are means of those in the three soil layers i.e. $0-30,30-60$ and $60-90 \mathrm{~cm}$.

Table (5): Comparison between chemical soil analysis in year 2012 and 2013 as percentage corresponding to year 1992 at the around area of well No.12

\begin{tabular}{|c|c|c|c|c|c|}
\hline & $\mathbf{1 9 9 2}$ & $\mathbf{2 0 1 2}$ & $\mathbf{2 0 1 3}$ & \%(1992-2012) & \%(2012-2013) \\
\hline $\mathrm{ECe}(\mathrm{dS} / \mathrm{m})$ & 4.38 & 6.23 & 6.43 & 42.2 & 3.2 \\
\hline $\begin{array}{c}\mathrm{K} \\
\mathrm{m} \mathrm{mol}_{\mathrm{c}} \mathrm{L}^{-1}\end{array}$ & 1.22 & 1.42 & 1.43 & 15.8 & 0.9 \\
\hline $\begin{array}{c}\mathrm{Na} \\
\mathrm{m} \mathrm{mol}_{\mathrm{C}} \mathrm{L}^{-1}\end{array}$ & 29.43 & 41.47 & 42.60 & 40.9 & 2.7 \\
\hline $\begin{array}{c}\mathrm{Mg} \\
\mathrm{m} \mathrm{mol}_{\mathrm{c}} \mathrm{L}^{-1}\end{array}$ & 9.25 & 13.49 & 13.84 & 45.7 & 2.6 \\
\hline $\begin{array}{c}\mathrm{Ca} \\
\mathrm{m} \mathrm{mol}_{\mathrm{c}} \mathrm{L}^{-1}\end{array}$ & 5.57 & 6.51 & 6.60 & 16.7 & 1.4 \\
\hline $\begin{array}{c}\mathrm{Cl} \\
\mathrm{m} \mathrm{mol}_{\mathrm{c}} \mathrm{L}^{-1}\end{array}$ & 27.23 & 38.60 & 40.03 & 41.7 & 3.7 \\
\hline $\begin{array}{c}\mathrm{SO} 4 \\
\mathrm{~m} \mathrm{~mol}_{\mathrm{c}} \mathrm{L}^{-1}\end{array}$ & 14.12 & 20.13 & 20.18 & 42.6 & 0.2 \\
\hline $\begin{array}{c}\mathrm{HCO} 3 \\
\mathrm{~m} \mathrm{~mol}_{\mathrm{C}} \mathrm{L}^{-1}\end{array}$ & 4.13 & 4.25 & 4.27 & 2.8 & 0.5 \\
\hline
\end{tabular}

See footnotes of table 4

Groundwater characteristics in El-Arish area

Acidity, cations and anions analysis

The $\mathrm{pH}$ indicates in general whether water is acidic or alkaline. The $\mathrm{pH}$ values for all samples were in accordance with normal $\mathrm{pH}$ range for drinking 
and irrigation water due to $\mathrm{FAO}$ (1985). The $\mathrm{pH}$ values ranged from 7.3 to 8.0 for all samples. Table (6) represents the chemical characteristics of the groundwaters of some studied wells in El Arish area.

Referring to the major cations, the sodium concentration of water samples ranged between 45 to $60 \mathrm{~m} \mathrm{~mol}_{\mathrm{c}} \mathrm{L}^{-1}$ which exceeded the permissible limit $\left(40 \mathrm{~m} \mathrm{~mol}_{\mathrm{c}} \mathrm{L}^{-1}\right)$ of $\mathrm{FAO}$ (1985). The magnesium exceeded the permissible limits of FAO (1985) for the samples $\left(5 \mathrm{~m} \mathrm{~mol}_{\mathrm{c}} \mathrm{L}^{-1}\right)$, whereas, the values of calcium for the samples were under the permissible limits $\left(20 \mathrm{~m} \mathrm{~mol}_{\mathrm{c}} \mathrm{L}^{-1}\right)$ of FAO (1985).

Referring to the major anions, high levels of chloride were observed in the samples and they exceeded the permissible limits $\left(30 \mathrm{~m} \mathrm{~mol}_{\mathrm{c}} \mathrm{L}^{-1}\right)$ of $\mathrm{FAO}$ (1985). The increases in sodium and chloride concentrations may be due to sea water intrusion that resulting from continuous pumping from the groundwater aquifer. The results of chemical analysis revealed that bicarbonate was under the permissible limits $\left(10 \mathrm{~m} \mathrm{~mol}_{\mathrm{c}} \mathrm{L}^{-1}\right)$ for well 5 but in well 12 bicarbonate concentration exceeded this limit. The sulphate varied from high to low according to FAO (1985). The concentration of $\left(\mathrm{SO}_{4}^{-}\right)$ exceeded the permissible limit of FAO (1985) in the two wells.

Table (6): Chemical analysis of some studied wells in El-Arish area, 2013

\begin{tabular}{|c|c|c|c|c|c|c|c|c|c|c|}
\hline \multirow{2}{*}{$\begin{array}{c}\text { Well } \\
\text { No. }\end{array}$} & \multirow{2}{*}{$\begin{array}{c}\mathrm{EC} \\
\mathrm{dS} / \mathrm{m}\end{array}$} & \multirow{2}{*}{ pH } & \multicolumn{4}{|c|}{ Cations $\left(\mathrm{m} \mathrm{mol}_{\mathrm{c}} \mathrm{L}^{-1}\right)$} & \multicolumn{3}{|c|}{ Anions $\left(\mathrm{m} \mathrm{mol} \mathrm{c}^{-1}\right)$} & \multirow{2}{*}{ SAR } \\
\hline & & & $\mathrm{K}^{+}$ & $\mathrm{Na}^{+}$ & $\mathrm{Mg}^{++}$ & $\mathrm{Ca}^{++}$ & $\mathrm{Cl}^{-}$ & $\mathrm{SO}_{4}{ }^{--}$ & $\mathrm{HCO}_{3}$ & \\
\hline 1 & 5.9 & 7.4 & 0.4 & 35.0 & 12.4 & 11.6 & 38.8 & 15.4 & 5.3 & 10.1 \\
\hline 2 & 8.8 & 7.9 & 0.8 & 54.6 & 19.8 & 12.6 & 59.0 & 21.0 & 7.8 & 13.6 \\
\hline 3 & 8.0 & 7.9 & 0.6 & 49.0 & 16.5 & 14.3 & 51.0 & 22.2 & 7.2 & 12.5 \\
\hline 4 & 6.4 & 7.8 & 0.9 & 36.0 & 14.7 & 12.2 & 39.0 & 17.6 & 7.2 & 9.8 \\
\hline 5 & 7.6 & 7.6 & 0.8 & 45.0 & 16.1 & 14.3 & 48.0 & 20.2 & 8.0 & 11.5 \\
\hline 6 & 5.5 & 7.3 & 0.6 & 34.0 & 12.3 & 8.6 & 40.0 & 8.8 & 6.7 & 10.5 \\
\hline 7 & 5.6 & 7.6 & 0.9 & 31.2 & 13.0 & 11.8 & 36.0 & 15.1 & 5.8 & 8.9 \\
\hline 8 & 5.8 & 7.7 & 0.8 & 31.0 & 14.1 & 11.6 & 36.4 & 14.9 & 6.2 & 8.6 \\
\hline 9 & 6.0 & 7.8 & 0.9 & 32.5 & 14.0 & 11.7 & 35.8 & 17.2 & 6.1 & 9.1 \\
\hline 10 & 7.5 & 7.6 & 0.9 & 41.0 & 18.3 & 14.8 & 43.0 & 24.6 & 7.4 & 10.1 \\
\hline 11 & 9.0 & 8.0 & 1.0 & 54.0 & 20.0 & 15.0 & 59.0 & 22.8 & 8.2 & 12.9 \\
\hline 12 & 10.5 & 8.0 & 0.9 & 60.5 & 23.9 & 19.7 & 66.0 & 27.7 & 11.3 & 13.0 \\
\hline
\end{tabular}

\section{The mathematical model \\ Model grid}

Depending on the geographical distribution of the measurements and hydrogeological information which were used to determine the dimensions of the model to cover the entire area. The model has been constructed with 120 columns, 120 rows, and one layer corresponding to 14400 cells. It covers an area of $21 \mathrm{~km}$ east and $20 \mathrm{~km}$ north with cell dimensions of $175^{\star} 175 \mathrm{~m}$.

\section{Boundary conditions of the study area}

The boundary conditions are the important key points in building a mathematical model. They reflect the behavior of the hydraulic movement of groundwater through the boundary of the mathematical model.The description of the boundary conditions that have been adopted for the water bearing layers are: 
- The Mediterranean Sea borders in the north. So, this boundary is modeled as a constant head boundary of value; zero, and it is modeled as a constant concentration for transport simulation having TDS $=40000 \mathrm{mg} \mathrm{L}^{-1}$.

- At the east and west side of the model the boundaries were chosen in such a way that they follow the regional directions of the groundwater flow. These two boundaries are modeled as no flow boundary.

- In the south, impervious boundary corresponding to the limit of the aquifer extension has been taken into account leading to adopting a no flow boundary.

- However, only the inlet of El-Arish valley at the south boundary of the study area has been considered as flow boundary whose value is obtained from Seguin and Bakr (1992).

\section{Input of the mathematical model}

The model-input data include all parameters that are used to develop a calibrated model, such as boundary conditions, hydraulic conductivity/ transmissivity, recharge, any additional model input; transient or steady state modeling.

\section{Pumping and observation wells data}

Figure (2) shows the locations of pumping and observation wells which were used for irrigation on the mathematical model. The observation wells data for 8 observed wells from year 1990 until 2013 were collected, this duration was divided into intervals 90 day each (i.e. from 90 to 8640 days) and also the water depth above mean sea level (a.m.s.l), and the screen depth were collected.

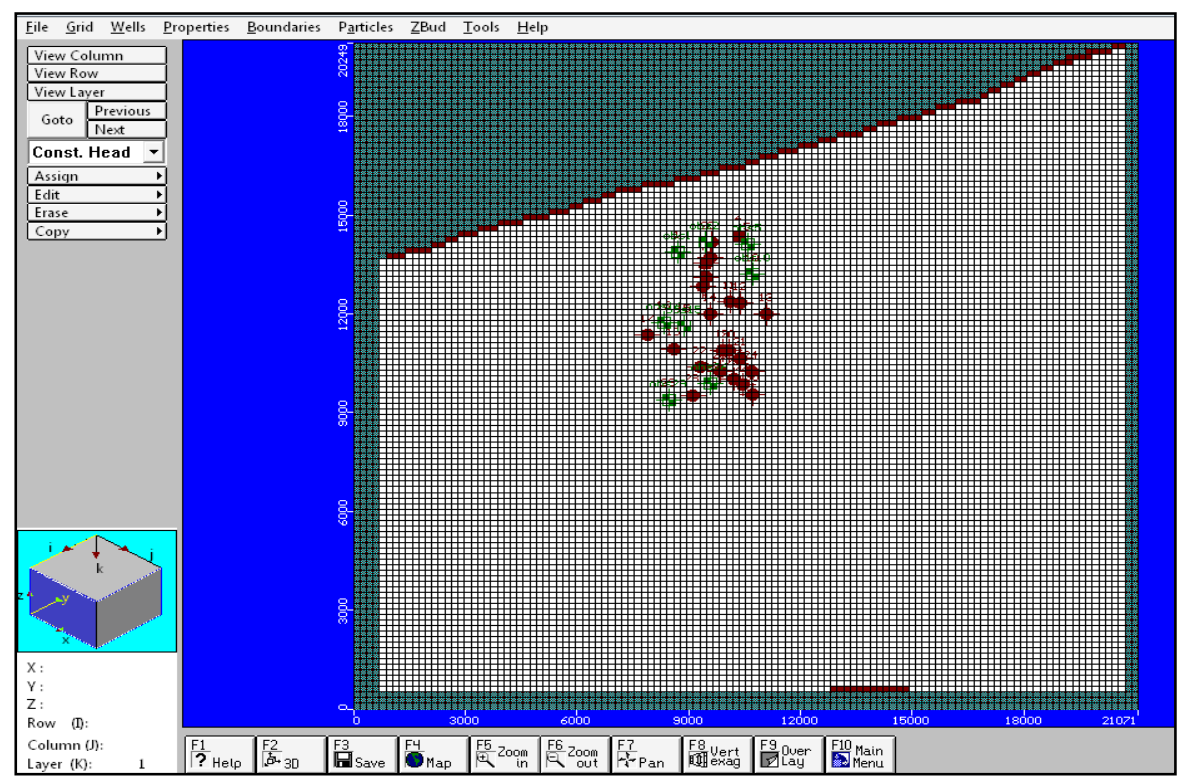

Fig (2): Locations of pumping and observation wells 


\section{Model calibration \\ Steady state calibration}

The steady state model was simulated for the year 1992. This year was selected because there are, relatively, comprehensive set of abstraction data. Calibration involved comparison of the model results and observation heads at a number of 8 target monitoring wells. After different changes in input parameters using trial-and-error process, the hydraulic conductivity values of the quaternary aquifer seemed ranging between 17 and $173 \mathrm{~m} /$ day.

\section{RESULTS OF SIMULATED SCENARIOS}

\section{First scenario}

This scenario represents the effect of continuous pumping rate from wells on the groundwater budget in the study area. By running the mathematical model according to this scenario, the values of drawdown in groundwater levels which are expected to be after ten years of application with $50 \%$ increasing in the pumping rate, showed that drawdown was increased with the time and the highest value of drawdown was $2.4 \mathrm{~m}$ in the observation well number 26 while the lowest value was $1.6 \mathrm{~m}$ in the observation well number 1.

\section{Second scenario}

In this scenario, the abstraction of groundwater from existing wells increased by two times the first scenario, which induced an increase of $100 \%$ in year (2033) with drought years (no rainfall). The values of drawdown in groundwater levels which are expected after twenty years of application showed that drawdown increased with the time and the highest value of drawdown was $6.17 \mathrm{~m}$ in the observation well number 26 whereas the lowest value was $3.93 \mathrm{~m}$ in the observation well number 1 .

\section{Third Scenario}

In this scenario, the extraction was the same as the second scenario but with assuming these years as rainy years. The values of drawdown in groundwater levels which are expected after twenty years of application showed that drawdown was increased with the time and the highest value of drawdown was $4.31 \mathrm{~m}$ in the observation well number 26 while the lowest value was $2.83 \mathrm{~m}$ the observation well number 1 .

After running the three scenarios by the model, it is clear that the second scenario has the highest values of drawdown as compared with the other scenarios. The maximum value of drawdown was $6.17 \mathrm{~m}$, whereas the lowest value of drawdown was $1.6 \mathrm{~m}$ for the observation wells 26 and 1 , respectively. These high values are due to the increase in drawdown by $100 \%$, Table(7) presents the predicted values of the drawdown of the groundwater in the observation wells under the proposed scenarios. 
Table (7): Comparison among the drawdown values $(m)$ under the different scenarios

\begin{tabular}{|c|c|c|c|}
\hline Observation well No. & $\begin{array}{c}\text { First } \\
\text { Scenario }\end{array}$ & $\begin{array}{c}\text { Second } \\
\text { Scenario }\end{array}$ & $\begin{array}{c}\text { Third } \\
\text { Scenario }\end{array}$ \\
\hline 1 & 1.60 & 3.93 & 2.83 \\
\hline 2 & 1.65 & 4.03 & 2.94 \\
\hline 5 & 1.84 & 4.53 & 3.23 \\
\hline 10 & 2.00 & 4.93 & 3.49 \\
\hline 15 & 2.00 & 5.00 & 3.61 \\
\hline 16 & 1.91 & 4.77 & 3.41 \\
\hline 26 & 2.40 & 6.17 & 4.31 \\
\hline 29 & 2.16 & 5.54 & 3.69 \\
\hline
\end{tabular}

\section{Groundwater salinity simulations}

Figure (3) shows the predicted values of the EC at 2023.This scenario is simulating the current situation after ten years. The contour lines of the groundwater salinity tended to be higher closes towards the sea, this reflects the impact of sea water intrusion on salinity of the groundwater.

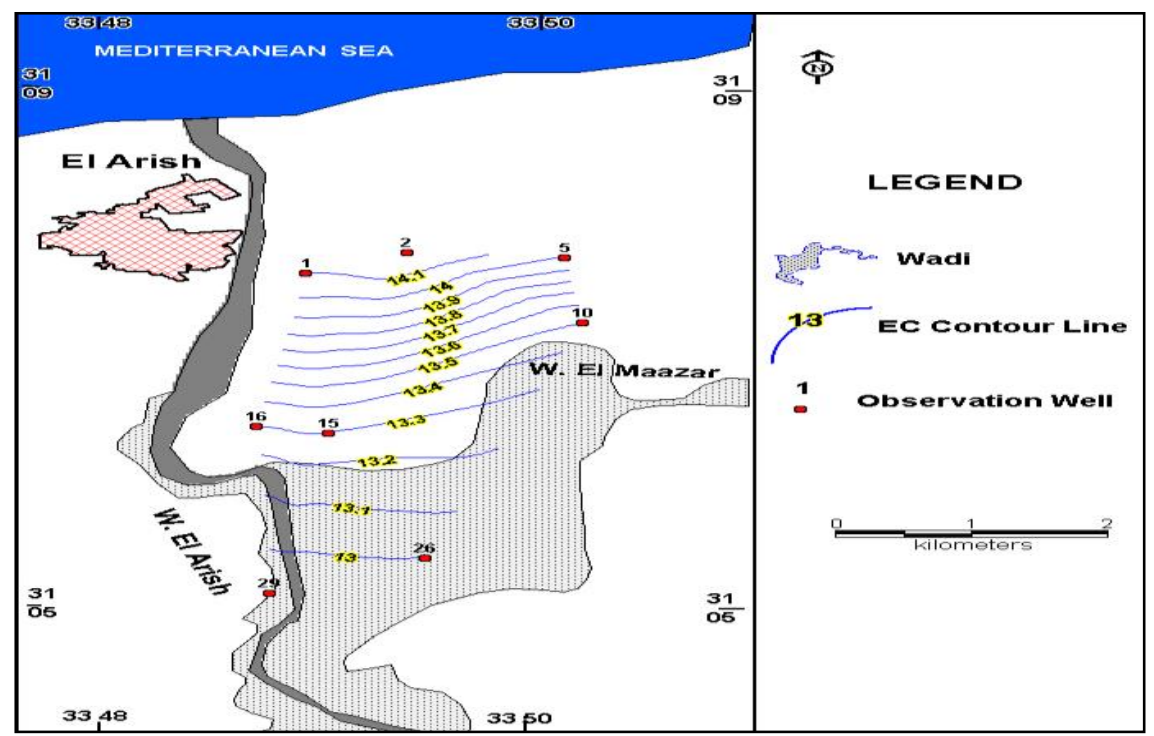

Figure (3): Salinity contour map for the observation wells in El Arish area (1 scenario)

Figure (4) and Figure (5) represent the predicted values of EC at 2033 under the other two scenarios. The first scenarois looks like the current one without occurrence of rainfall while the second simulate the case with occurrence of rainfall. The trend of the contour lines which expressed the EC was similar in the two figures with the exception in the distance between the contour lines in both of them. The tendency of increasing the values of EC towards the sea was clear in both figures due to the sea water intrusion. 


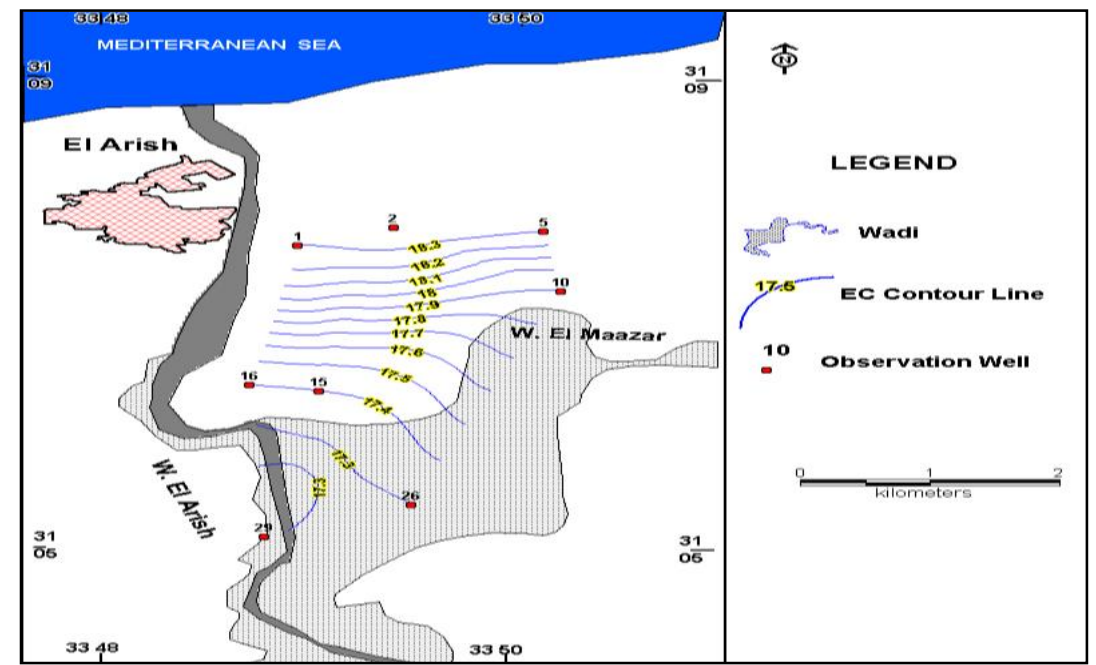

Figure (4): Salinity contour map for the observation wells in El Arish area $\left(2^{\text {nd }}\right.$ scenario

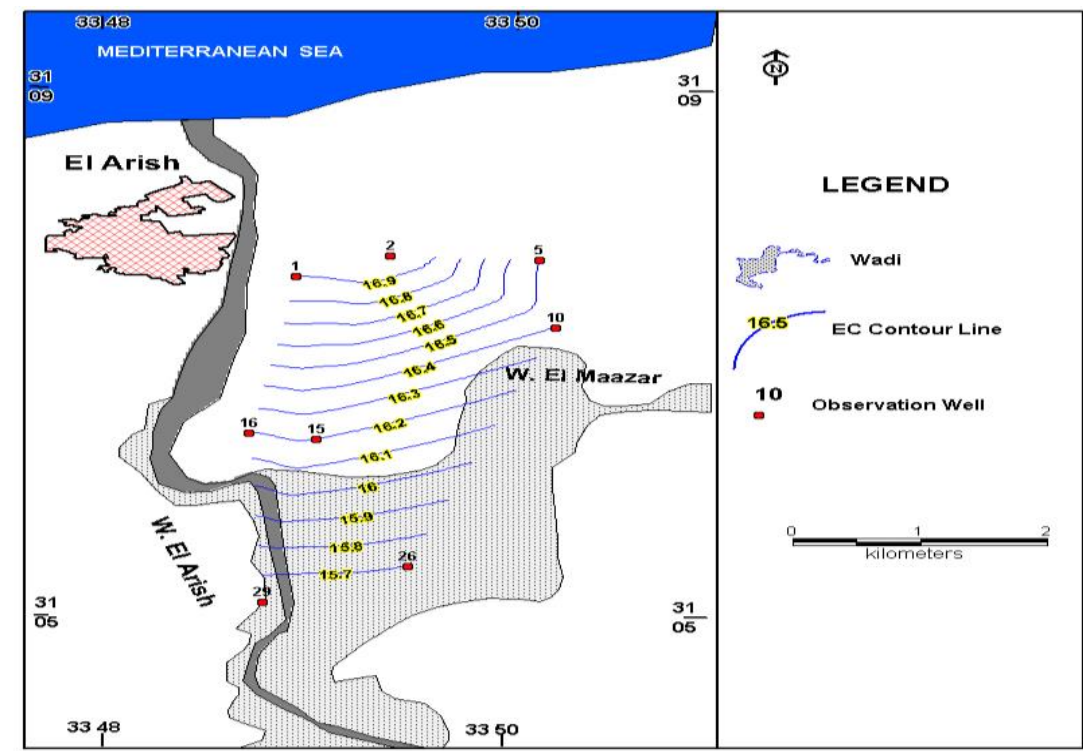

Figure (5): Salinity contour map for the observation wells in El Arish area ( $3^{\text {rd }}$ scenario)

Obviously, the occurrence of rainfall in the third scenario which takes into account the recharge of the groundwater aquifer contributed to mitigation of the groundwater salinity to some extent as compared to the second scenario. 
Finally, from the data of the drawdown and the salinity values in the three proposed scenarios, it is clear that wells (26) and (29) have high values of the drawdown but at the same time they have lower values of EC. In contrary, well (1) and (2) have lower values of the drawdown, but they have high values of the EC. This occurred due to variations in the locations of these wells .Well (1) and (2) are nearer to the sea than wells (26) and (29) which are farther from the sea.

Data of predicted EC presented in Table (8) show that in absence of rainfall, the predicted values by the model at 2023(1st scenario) will range between 12.9 and $14.2 \mathrm{dS} / \mathrm{m}$ which, means that the values of soil EC will range between 19.3 and $21.3 \mathrm{dS} / \mathrm{m}$ due to the equation edited by $\mathrm{FAO}$ (1985): $\quad \mathrm{EC}_{\text {soil }}=\mathrm{EC}_{\text {water }}$ * 1.5

The same trend will occur for the values of EC predicted by the model in 2033 with and without rainfall, where the predicted values of EC of the studied wells will range between 17.3 and $18.4 \mathrm{dS} / \mathrm{m}$ without rainfall and 15.6 and $17.0 \mathrm{dS} / \mathrm{m}$ with rainfall. This means that the soil EC at 2033 will be very high and soil will change into saline soil and consequently it will not be available for agriculture or cultivating even tolerant crops.

Table (8): Predicted EC values of wells' waters and calculated EC of soil under different studied scenarios

\begin{tabular}{|c|c|c|c|c|c|c|c|}
\hline $\begin{array}{c}\text { Observation } \\
\text { well }\end{array}$ & $\begin{array}{c}\text { Current } \\
\text { State } \\
\left(\mathrm{EC}_{\mathrm{w}}\right)\end{array}$ & $\begin{array}{c}\text { First } \\
\text { scenario } \\
\left(E_{\mathrm{w}}\right)\end{array}$ & $\begin{array}{l}\text { Predicted } \\
\mathrm{EC}_{\mathrm{e}}\end{array}$ & $\begin{array}{c}\text { Second } \\
\text { scenario } \\
\left(E_{w}\right)\end{array}$ & $\begin{array}{c}\text { Predicted } \\
E^{-} C_{e}\end{array}$ & $\begin{array}{c}\text { Third } \\
\text { scenario } \\
\left(\mathrm{EC}_{\mathrm{w}}\right)\end{array}$ & $\begin{array}{c}\text { Predicted } \\
\mathrm{EC}_{\mathrm{e}}\end{array}$ \\
\hline 1 & 5.9 & 14.1 & 21.2 & 18.3 & 27.4 & 16.9 & 25.3 \\
\hline 2 & 6.7 & 14.2 & 21.3 & 18.4 & 27.5 & 17.0 & 25.5 \\
\hline 5 & 5.8 & 14.0 & 21.1 & 18.3 & 27.4 & 16.5 & 24.8 \\
\hline 10 & 5.7 & 13.5 & 20.3 & 17.9 & 26.9 & 16.4 & 24.6 \\
\hline 15 & 6.1 & 13.3 & 19.9 & 17.4 & 26.1 & 16.2 & 24.4 \\
\hline 16 & 5.1 & 13.3 & 19.9 & 17.4 & 26.0 & 16.2 & 24.3 \\
\hline 26 & 6.8 & 13.0 & 19.5 & 17.3 & 26.0 & 15.7 & 23.6 \\
\hline 29 & 5.7 & 12.9 & 19.3 & 17.3 & 25.9 & 15.6 & 23.4 \\
\hline
\end{tabular}

\section{Crop yield response to salinity}

The relation between the soil salinity and crops yield presented by the equation proposed by FAO (1985) and published by (Maas and Grattan (1999): $Y=100-b\left(E C_{e}-a\right)$ was used to predict the impact of the soil salinity on some crops yield that cultivated in the studied area. Maas and Grattan (1999) provided an extensive list of salinity coefficients for a number of agronomic crops as shown in Table (9).

Table (9): Relative salt tolerance of various crops

\begin{tabular}{|c|c|c|}
\hline Crop & a(threshold $\left.\mathbf{E C}_{\mathbf{e}}\right) \mathbf{~ d S} / \mathbf{m}$ & b, slope $(\%$ per/dS $/ \mathbf{m})$ \\
\hline Barley & 8.0 & 5.0 \\
\hline Maize & 1.7 & 12.0 \\
\hline Tomato & 0.9 & 9.0 \\
\hline Wheat & 4.5 & 2.6 \\
\hline Broad Beans & 1.6 & 9.6 \\
\hline
\end{tabular}

Maas and Grattan (1999) 
Subsequently, the pervious equation of relative yield has been applied for some crops which already cultivated in El Arish area. The relative crop yield has been calculated with the highest $\mathrm{EC}_{\mathrm{e}}$ of the soil saturation extract (7.5 $\mathrm{dS} / \mathrm{m})$. The data reveal that the effect of increasing the soil salinity on the crops productivity especially for the sensitive crops and also a little effect for the tolerant crops. This was the current situation. Regarding the predicted results of the groundwater salinity from the model and the predicted salinity of the soil by the FAO equation, it is clear that the relative crop yield will decrease sharply for different crops due to the high saline soil in the future.

\section{REFERENCES}

Askin, T., and Özdemir, N., (2003) soil bulk density as related to soil particle size distribution and organic matter content. Samsun meteorology bulletin reports. Samsun, Turkey.

Black, (1965). "Methods of Soil Analysis". Part (1) "Agronomy" American society of Agronomy, Inc., Madison Wisconsin, USA.

FAO - Food and Agriculture Organization (1985). Water quality for agriculture. Ayers R.S. and Westcot D.W. FAO Irrigation and Drainage Paper 29, Rev. 1. FAO, Rome. $174 \mathrm{p}$.

Hesse, P. R. (1971). "A text book of soil chemical analysis". Chemical Publishing Co., NY.

Jackson, M.L. (1973). "Soil chemical analysis." prentice Hall inc. N. J.

JICA, (1992).North Sinai Groundwater Resources Study in Egypt, Final Report. Unpublished Report, Cairo-Egypt.

Lacirignola, C., Hamdy A. and Trisorio Liuzzi, G. (2002). The integration of soil and water resources management towards a sustainable agricultural development in the Mediterranean.The $7^{\text {th }}$ International meeting on soils with Mediterranean type of climate. Options Mediterranean. Series A: Mediterranean seminars. N 50.CIHEAM- MAI Bari (Italy).

Maas, E.V., and Grattan. S. R. (1999). Crop yields as affected by salinity in Skaggs R. W. and Van Schilfgaarde J., eds., Agricultural Drainage Agron. Monograph 38 ASA, CSSA, SSSA, Madison, WI.

NRCCA (Northeast Region Certified Crop Adviser), (2009). Soil and water management-study guide. Cornell University.

Piper, C.S. (1950). "Soil and Plant Analysis". Inter. Science Publisher, Inc., N.Y., USA.

Richards LA (1954) Saline and alkali soil - United States agriculture handbook no. 60: 84.

Seguin, J. J., and Bakr, M. (1992). Sinai Water Resources Study, Modelling of three aquifers: El Arish, Rafah, and El Qaa, WRRI, NWRC, Egypt, 1992.

Singh, D., Chhonkar, P. K. and Dwivedi, B. S. (2007). Manual on soil, plant and water analysis. Westville Publishing House, New Delhi.

USDA (2004) "Soil survey laboratory methods manual" Soil survey investigation report No. 42 version 4.0 November 2004. 
Walker, W.R. and Skogerboe, G.V. (1987). Surface irrigation: Theory and Practice. Prentice-Hall, Englewood Cliffs, New Jersey. 386p.

\section{اسـتخدام بعض النمـاذج الرياضية للتنبؤ بنوعيـة الميـاه الجوفيـة وانتاجيـة التربـة

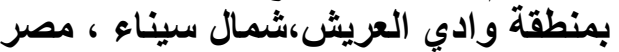

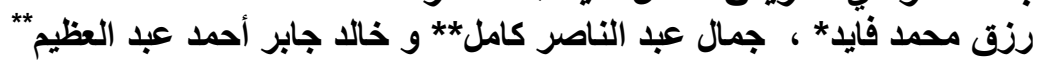

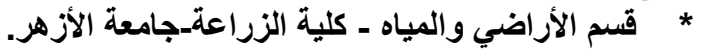

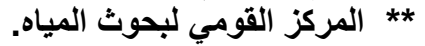

تعتبر المياه الجوفية الصددر الرئيسي للاري في شمال سيناء في منطقة وادي العريش. وترجع زئر زيادة

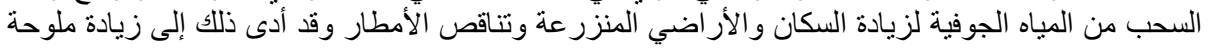

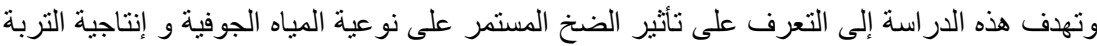

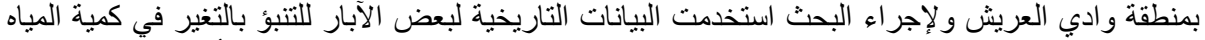

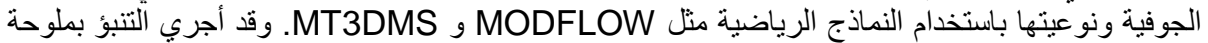

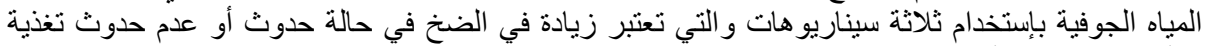
بالأمطار لمدة الئاه 10 أو 20 سنة مستقبلا.

ومن البيانات المتوقعة من النموذج الرياضي للمياه الجوفية تم حساب ملوحة التربة باستخدام المعادلة : (1.5

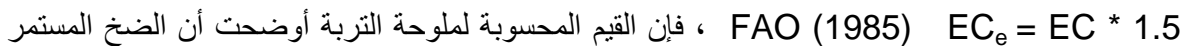

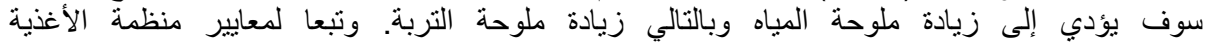

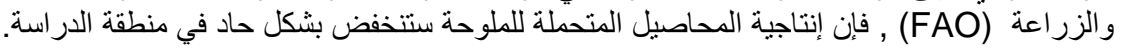

